5. Robocha prohrama z inozemnoi movy (anhliyskoyi) dlya studentiv spetsialnosti "Skhidni movy" [Work program for foreign language (English) for students of the specialty "Oriental languages"]. - Kyiv: KNU imeni Tarasa Shevchenka Publ., 2017. - 48 p.

6. Robocha prohrama $\mathrm{z}$ pershoyi inozemnoyi movy (anhliyskoyi) dlya studentiv za napryamom pidhotovky 6.020303 Filolohiya (Pereklad (anhliyska)) [Working program for the first foreign language (English) for students in the field of study 6.020303 Philology (Translation (English))]. - Kyiv: KNLU publ., 2015. - 76 p.

7. Negle S. J. Comprehension Theory and Second Language Pedagogy / S. J. Negle, S. L. Sanders // TESOL Quarterly. - 1986. - Vol. 20. - № 1.- P. 9-26.

Стаття надійшла в редакиію 29.05.2018 p.

УДК 377: 811.111

IRYNA SKRIL

ID ORCID 0000-0002-5252-0521

iryna.skril@gmail.com

Senior Lecturer

Lviv Professional College of Hospitality, Tourism and Restaurant Service

Lviv, 36 Puliui St.

\title{
PECULIARITIES OF LESSON PLANNING AND ITS RUNNING IN TEACHING ENGLISH FOR SPECIFIC PURPOSES FOR PROSPECTIVE SPECIALISTS IN HOSPITALITY AND RESTAURANT SERVICE
}

The article analyses the peculiarities of lesson planning in teaching English for Specific Purposes (ESP) for prospective experts in hospitality and restaurant service. The importance of teaching English for professional uses and particularly in the field of hospitality and restaurant service is undeniable. English proficiency is required in all professional areas but it becomes essential in the hospitality industry because of its specific characteristics. Setting objectives, designing lesson planning and developing lesson plans are necessary logical steps in the process of lesson implamentation in teaching ESP for prospective experts in hospitality and restaurant service. The stages of lesson plan are shown. Examples of learning objectives, learning activities and assessment for prospective experts in hospitality and restaurant service are presented. The artile emphasizes the importance of practical usage of theoretical language knowledge, stresses the peculiarities of lesson planning and explores various conditions, stages and organizational forms with their impact on the process of teaching ESP for prospective experts in hospitality and restaurant service.

Keywords: English for Specific Purposes (ESP), lesson planning, learning objectives, learning activities, assessment.

ІРИНА СКРІЛЬ

Старший викладач Львівський професійний коледж готельно-туристичного та ресторанного сервісу м. Львів, вул. І. Пулюя, 36

\section{ОСОБЛИВОСТІ ПЛАНУВАННЯ І ПРОВЕДЕННЯ НАВЧАЛЬНИХ ЗАНЯТЬ 3 ІНОЗЕМНОЇ МОВИ ЗА ПРОФЕСІЙНИМ СПРЯМУВАННЯМ ДЛЯ МАЙБУТНІХ ФАХІВЦІВ ГОТЕЛЬНО-РЕСТОРАННОЇ СПРАВИ}

\footnotetext{
Аналізуються особливості планування навчальних занять з іноземної мови за професійним спрямуванням (ІМПС) для майбутніх фахівців готельно-ресторанної справи. Важливість викладання англійської мови для професійного використання, особливо в сфері гостинності та ресторанного обслуговування, є незаперечною. Вказано, що досконале володіння англійською мовою потрібне у всіх професійних сферах, зокрема в індустрії гостинності завдяки своїм специфічним характеристикам. Постановка цілей, проектування планування і створення планів навчальних занять розглянуто як необхідні логічні кроки у процесі проведення занять для навчання іноземної мови за професійним спрямуванням для майбутніх фахівців готельного та ресторанного обслуговування. Показано етапи реалізації плану навчальних занять. Представлено приклади навчальних иілей, навчальна діяльність та оцінювання майбутніх фахівців готельно-ресторанної справи. Відзначено актуальність практичного
} 
використання теоретичних мовних знань, особливості планування навчальних занять. Досліджено різні умови, етапи та організаційні форми з їх впливом на процес навчання ІМПС для майбутніх фахівців готельно-ресторанної справи.

Ключові слова: іноземна мова за професійним спрямуванням, планування навчальних занять, иілі навчання, навчальна діяльність, оцінювання.

ИРИНА СКРИЛЬ

старший преподаватель

Львовский професиональный коледж гостиннично-туристического и ресторанного сервиса

г. Львов, ул. И. Пулюя, 36

\title{
ОСОБЕННОСТИ ПЛАНИРОВАНИЯ И ПРОВЕДЕНИЯ УЧЕБНЫХ ЗАНЯТИЙ ПО ИНОСТРАННОМУ ЯЗЫКУ ПО ПРОФЕССИОНАЛЬНОМУ НАПРАВЛЕНИЮ ДЛЯ БУДУЩИХ СПЕЦИАЛИСТОВ ГОСТИННИЧНО- РЕСТОРАННОГО ДЕЛА
}

\begin{abstract}
Анализируются особенности планирования учебных занятий по иностранному языку по профессиональному направлению (ИЯПН) для будущих специалистов гостинично-ресторанного дела. Важность преподавания английского языка для профессионального использования, особенно в сфере гостеприимства и ресторанного обслуживания, является неоспоримым. Указано, что владение английским языком необходимо во всех профессиональных сферах, вчастности в индустрии гостеприимства благодаря своим специфическим характеристикам. Постановка иелей, проектирования планировки и создания планов учебных занятий направлено как необходимые логические шаги в прочессе проведения занятий для обучения иностранному языку по профессиональному направлению для будущих специалистов гостиничного и ресторанного обслуживания. Показань этапь плана учебных занятий. Представлены примеры учебных целей, учебная деятельность и оценивание будущих специиалистов гостинично-ресторанного дела. Отмечена актуальность практического использования теоретических языковых знаний, особенности планирования учебных занятий. Исследованы различные условия, этапы и организаџионные формы с их влиянием на процесс обучения ИМПС для будущих специиалистов гостинично-ресторанного дела.
\end{abstract}

Ключевые слова: иностранный язык профессионального направления (ИЯПН), планирование учебных занятий, цели обучения, учебная деятельность, оценивание.

At the present stage the necessary condition for learning a foreign language is the introduction of such methods and techniques that would more effectively reveal the potential of students, their intellectual, creative and personal qualities. Implementation of foreign language communicative competence is the basis of their professional activities.

Many Ukrainian institutions have begun revamping their English for Specific Purposes (ESP) programs to bring them in line with the needs of local employers. These reforms recognize the correlation between what students learn in class and success in their future professions. Therefore, a main objective of English departments is to ensure that ESP courses impart the key communicative skills that are most useful to graduates in their chosen careers. From the hotel receptionist at the front desk to restaurant manager, English proficiency is required to carry out business.

Lesson planning is a critical part of overall course design. Once we have designed our entire course (including the structure and sequence, the tools we will use, and delivery method), mapping and aligning the course objectives (and the individual learning objectives for each lesson) to the assessments, occur most successfully during the lesson planning stage. Alignment must occur between assessments and objectives to have successful student outcomes. This defines the importance of lesson planning in teaching ESP for prospective experts of hospitality and restaurant service.

The problem of teaching a foreign language for students of non-target orientation has been analyzed by scholars such as O. Bihych, I. Bim, V. Buhbinder, I. Zadorozhna, O. Kvasova, A. Knurova, L. Morska, N. Mykytenko, N.Minina, S. Nikolaieva, Ye. Passov, I. Popov, I. Simkova, I. Semeriak, D.Tereschuk etc. The analysis of contentual components of the professionally oriented learning has been studied N. Castle, M. Kokor, N. Rubel, O. Tarnopolskyi, O. Tynkaliuk, L. Zienia etc. However, despite great attention given to the subject, lesson planning in teaching ESP remains of interest to scholars, especially those working in the field of education. 
The purpose of the article is to analyse percularities of lesson planning and implementation in teaching ESP for prospective experts of hospitality and restaurant service.

From a teaching point of view the emphasis is firmly on functional language - giving information, making recommendations, dealing with problems and so on - and on creating realistic situational practice where language functions can be demonstrated and developed alongside basic service-oriented performance. In English for Specific Purposes, "language is learnt not for its own sake or for the sake of gaining a general education, but to smooth the path to entry or greater linguistic efficiency in academic, professional or workplace environments" [4, p. 18].

Hospitality is an industry where communication is the key feature. It is also an international industry and will involve a range of inter-cultural encounters. The language of this industry is quite clearly English in an international context, but it is also the language of meeting needs, of providing high levels of service, of understanding people, of delighting people, of solving problems.

Lesson planning is an important aspect of effective teaching because it focuses the teaching on the students. It is defined as "a description or outline of (a) the goals or OBJECTIVES a teacher has set for a lesson (b) the activities and procedures the teacher will use to achieve them, the time to be allocated to each activity, and the order to be followed, and (c) the materials and resources which will be used during the lesson" [9, p. 333]. However, lesson planning can seem overwhelming and laborious.

Lesson plans are a road map to facilitate teaching and learning, what students need to learn and how it will be done effectively during the class time. Then appropriate learning activities are designed and strategies to obtain feedback on student learning re developed. Having a carefully constructed lesson plan entering the classroom is with more confidence and maximizing chance of having a meaningful learning experience with students.

The structure of the lesson is determined by its content and place in the cycle of lessons. Traditionally, the lesson consists of stages. The concept of the stage is associated with the movement to the goal set within a certain period of time, so the stage is established in didactics as a structural unit of the lesson. However, only one set of stages of a lesson, located in a certain sequence, does not form its structure. The structure of the lesson is determined by a set of regularities of its internal organization, according to how the stages are composed [1, p. 472].

A successful lesson plan addresses and integrates three key components:

Learning Objectives;

Learning activities;

Assessment to check for student understanding.

A lesson plan provides us with a general outline of our teaching goals, learning objectives, and means to accomplish them, and is by no means exhaustive. A productive lesson is not one in which everything goes exactly as planned, but one in which both students and instructor learn from each other.

Before planning lesson to identification the learning objectives for the lesson is first needed. A learning objective describes what the learner will know or be able to do after the learning experience rather than what the learner will be exposed to during the instruction (i.e. topics). Typically, it is written in a language that is easily understood by students and clearly related to the program learning outcomes.

The Bloom's Revised Taxonomy of Educational Objectives is a useful resource for crafting learning objectives that are demonstrable and measurable. Anderson and Krathwohl's revision of the original Bloom's taxonomy redefines the cognitive domain as the intersection of the Cognitive Process Dimension and the Knowledge Dimension [3, p.44-46, 67-68]. Although the Cognitive Process and Knowledge dimensions are represented as hierarchical steps, the distinctions between categories are not always clear-cut. For example, all procedural knowledge is not necessarily more abstract than all conceptual knowledge; and an objective that involves analyzing or evaluating may require thinking skills that are no less complex than one that involves creating. It is generally understood, nonetheless, that lower order thinking skills are subsumed by, and provide the foundation for higher order thinking skills.

Writing objectives is important stage of a lesson. There are two models for English Language Learning:

Model 1: Terminal (Main) and Enabling (Supporting). In this model, the teacher will identify two types of objectives: terminal (main) and enabling (supporting). This model is useful when the main goal of the students' learning is communication skill in English. Students whose lessons follow 
the terminal-enabling path may be learning other things along with their English, but English learning is viewed as the ultimate goal.

Terminal Objective: the overall communicative outcome of the lesson or unit of study. What should the students be able to do in real life by using English that they could not do before the lesson or unit?

Enabling Objectives: The subskills that students need to acquire in order to succeed in the terminal task. Exactly what to the students need to become able to do that will allow them to meet the terminal objective? Terminal (main) and enabling (supporting) objectives are shown below:

Lesson Plan - Hospitality

Topic: Clothes. Taking requests

Terminal Objectives:

1. Students will be able to provide basic information about clothes.

2. Students will be able to make appropriate responses to the guest's requests in reception and to help directly, or need to contact room service or housekeeping.

Enabling Objectives:

1. Students will be able to list the following clothes: T-shirt, blouse, jumper, skirt, dress, shorts, jeans, jacket, coat, cap, hat, scarf, gloves, mittens, socks, shoes, boots, flip-flops.

2. Students will be able to identify clothes needed for different occasions.

3. Students will be able to practice the structures with need and use the verbs to make sentences about what needs doing.

4. Students will be able to give good customer service.

Model 2: Cognitive Academic Language Learning Approach (CALLA).

In this model, the teacher will identify three types of objectives: cognitive objectives, learning strategies objectives, and language objectives. This model is useful when the students are trying to use English in order to learn something else. The CALLA model was developed for the context of regular elementary and high school education, where the ultimate goal is success in core academic subjects and English is just one of the things that has to be done in order to make the learning of academic subjects possible.

Cognitive Objective: The subject-area learning that the student needs to master during the lesson. Usually the main cognitive objective is the main objective for the lesson as a whole.

Learning Strategies Objective: A skill that the student needs to master in order to become an effective learner. Learning strategies can include study skills, methods of investigation, social skills that will permit cooperative learning, and any other ability that will help the student learn both in the current lesson and in the future.

Language Objective: A particular piece of English language skill that the student must acquire in order to meet the cognitive and learning strategies objectives.

The balance between Cognitive, Learning Strategies and Language objectives may be very different from one lesson to another, depending on the students' current level of language and learning strategy knowledge in relation to the content objectives that they must meet. Early in a unit of study, most of the attention may have to be given to language and learning strategies. Gradually, as relevant language and learning skills increase, the students will become able to focus more heavily on the cognitive (subject area) content.

A particular group of students may benefit more from one of these two models than from the other. Most groups will benefit from one model on some occasions and the other model on other occasions. The teacher's choice of models will always depend on the needs and abilities of the students at that particular point in their course of study, and on the main purposes of the program in which the students are enrolled.

As the name suggests, the CALLA approach was developed for use in contexts where academic learning is the main purpose of the program. Usually, students in CALLA-based lessons are focused most on the learning of other subjects, and have to learn English because English is the medium in which the subjects are being taught. Students in terminal/enabling lessons have the learning of English itself as their main goal. Although they may also need to learn other kinds of knowledge, usually they already have basic knowledge of the topic area; they may need to learn about a new cultural context for a particular topic, but they bring some knowledge of the topic with them from their first language. The example of CALLA objectives is given below: 
Lesson Plan - Food Production

Content Objective:

Students will be able to plan a menu that showcases Ukrainian foods to a Canadian tour group.

Learning Strategies Objectives:

Students will be able to use questions to determine which Ukrainian foods are commonly eaten by non-Ukrainians in Canada.

Language Objectives:

Students will be able to use the sentence tag, "Do you eat..." in order to elicit information.

Students will be able to give simple descriptions of a dish, including appearance, basic ingredients and methods of preparation.

To analyse the target situation, it is used the framework presented by T. Hutchinson and A. Waters $[8$, p. 59]. The students need the language for a combination of study, work and training. For their future work it will be essential to be able to deal with the situations on the grounds of the hotel facilities and hotel restaurant. The topics related to food and travelling are an integral part of the expected output of the students' knowledge. To be more specific, the oral part of the lessons includes questions about travelling, eating habits at home and the restaurants.

After identifying areas (related to the subject Hotel management in English), where the students may work after graduating (a hotel, restaurant), considering the types of jobs they may find there (a waiter, head waiter, restaurant manager, receptionist), and analysing the situations they are likely to find themselves in, the objectives are as follows:

Students will be familiar and able to use specific vocabulary related to gastronomy, restaurant and hotel environment.

Students will be familiar and able to use specific phrases connected to restaurant and hotel jobs.

Students will be able to read and understand menus and booking in written form. writing.

Students will be capable of writing down booking notes and present confirmation of booking in

Students will be able to take the details of booking from a telephone conversation.

Approach is a theoretical position in language learning, of how people learn in general. According to J. Harmer a method is the practical realisation of an approach [6, p. 78]. That implies application of an approach from the context of language teaching, a plan for presenting the language material to be learned.

When planning learning activities the types of activities are considered students will need to engage in, in order to develop the skills and knowledge required to demonstrate effective learning in the course. Learning activities should be directly related to the learning objectives of the course, and provide experiences that will enable students to engage in, practice, and gain feedback on specific progress towards those objectives.

Planning learning activities it is necessary to estimate how much time will be spent on each. Building in time for extended explanation or discussion is needed to include in learning activities, but also being prepared to move on quickly to different applications or problems, and to identify strategies that check for understanding is important to realize.

Many activities can be used to engage learners. The activity types (i.e. what the student is doing) and their examples provided below are by no means an exhaustive list, but will help teacher in thinking through how best to design and deliver high impact learning experiences for students in a typical lesson (Table 1).

Table 1

List of learning activities and their description

\begin{tabular}{|c|c|c|}
\hline Activity type & $\begin{array}{l}\text { Learning } \\
\text { activities }\end{array}$ & Description \\
\hline $\begin{array}{l}\quad \text { Interaction with } \\
\text { content } \\
\text { Students are more }\end{array}$ & $\begin{array}{l}\text { Drill and } \\
\text { practice }\end{array}$ & $\begin{array}{l}\text { Problem/task is presented to students where they } \\
\text { are asked to provide the answer; may be timed or } \\
\text { untimed }\end{array}$ \\
\hline $\begin{array}{l}\text { likely to retain } \\
\text { information } \\
\text { presented }\end{array}$ & Lecture & $\begin{array}{l}\text { Convey concepts verbally, often with visual aids } \\
\text { (e.g. presentation slides) }\end{array}$ \\
\hline $\begin{array}{l}\text { in these ways if they are } \\
\text { asked to interact with }\end{array}$ & Quiz & $\begin{array}{l}\text { Exercise to assess the level of student } \\
\text { understanding and questions can take many forms, e.g. }\end{array}$ \\
\hline
\end{tabular}


ЛІНГВОДИДАКТИКА

\begin{tabular}{|c|c|c|}
\hline \multirow{2}{*}{$\begin{array}{l}\text { the material in some } \\
\text { way. }\end{array}$} & & multiple-choice, short-structured, essay etc. \\
\hline & $\begin{array}{l}\text { Student } \\
\text { presentation }\end{array}$ & $\begin{array}{l}\text { Oral report where students share their research on } \\
\text { a topic and take on a position and/or role }\end{array}$ \\
\hline \multirow{3}{*}{$\begin{array}{l}\text { Problem solving } \\
\text { and Critical thinking } \\
\text { Presenting students } \\
\text { with a problem, } \\
\text { scenario, case, } \\
\text { challenge or design } \\
\text { issue, which they are } \\
\text { then asked to addressor } \\
\text { deal with provides } \\
\text { students with } \\
\text { opportunities to think } \\
\text { about or use knowledge } \\
\text { and information in new } \\
\text { and differentways }\end{array}$} & Case Study & $\begin{array}{l}\text { Detailed story (true or fictional) that students } \\
\text { analyse in detail to identify the underlying principles, } \\
\text { practices, or lessons it contains }\end{array}$ \\
\hline & $\begin{array}{l}\text { Concept } \\
\text { Mapping }\end{array}$ & $\begin{array}{l}\text { Graphical representation of related information in } \\
\text { which common or shared concepts are linked together }\end{array}$ \\
\hline & $\begin{array}{l}\text { Real-world } \\
\text { projects }\end{array}$ & $\begin{array}{l}\text { Planned set of interrelated tasks to be executed } \\
\text { over a fixed period and within certain cost and other } \\
\text { limitations, either individually or collaboratively }\end{array}$ \\
\hline $\begin{array}{l}\text { Reflection } \\
\text { The process of } \\
\text { reflection starts with the } \\
\text { student thinking about } \\
\text { what they already know } \\
\text { and have experienced in } \\
\text { relation to the topic } \\
\text { being explored/learnt. } \\
\text { This is followed by } \\
\text { analysis of why the } \\
\text { student thinks about the } \\
\text { topic in the way they do, } \\
\text { and what assumptions, } \\
\text { attitudes and beliefs } \\
\text { they have about, and } \\
\text { bring to learning about } \\
\text { the topic. }\end{array}$ & $\begin{array}{l}\text { Reflection } \\
\text { journal }\end{array}$ & $\begin{array}{l}\text { Written records of students' intellectual and } \\
\text { emotional reactions to a given topic on a regular basis } \\
\text { (e.g. weekly after each lesson) }\end{array}$ \\
\hline
\end{tabular}

It is important that each learning activity in the lesson must be aligned to the lesson's learning objectives, meaningfully engage students in active, constructive, authentic, and collaborative ways, and useful where the student is able to take what they have learnt from engaging with the activity and use it in another context, or for another purpose. There is a predictable connection between each communicative function and certain linguistic expressions [10, p. 18].Two examples of learning activities for ESP lesson planning:

Lesson Plan - Food Production

Activities:

1.Teacher will display map of Canada, pointing out the provinces where many Ukrainian families have settled. Students will practice the names of the four provinces: Ontario, Manitoba, Saskatchewan, Alberta.

Because we have many Ukrainian families, most Canadians are used to eating some kinds of Ukrainian food.

Students must ask the teacher questions (Do you eat in Canada?) to find out which Ukrainian foods are common in Canada. Chart items that are eaten and not eaten on the white board. Cabbage rolls, perogie, borscht and sausage are very common, but other traditional Ukrainian foods aren't common. What are your favourite traditional foods?

2. Situation: A group of Canadian visitors is coming here. They own restaurants and they want to learn about traditional Ukrainian food. You will be preparing a meal for them that showcases traditional Ukrainian food. Define showcase if they don't know the word. In your notebook, list some traditional foods that you might want to include in the menu. Solo activity, 2-3 minutes 
3. Divide the room into mixed ability groups of 3 or 4 . Each group has 10 minutes to prepare a balanced menu that will showcase traditional Ukrainian food. Circulate to make sure groups are on task and to provide needed vocabulary.

4. Each group will present their menu. Write menus on the white board. If a new item comes up, ask the group to describe it.

Lesson Plan - Hospitality

What would you wear to a party? I'd wear mini-skirt. What about you?

(to go running, to go out in the snow, to go on holiday)

Structure to practice: Use need in the following ways:

as a main verb (need + noun) need=require

I need my trousers this afternoon.

as an auxiliary verb (need + -ing) passive meaning

I think the room needs cleaning.

as an auxiliary verb (need + full infinitive) need=have to

I need to change towels every day

Students work in pairs.

1. Using the verbs to make sentences about what needs doing.

2. Role-play

3 Steps to Good Customer Service

1. Greet the guest (Good morning)

2. Listen and understand the request

(Two more towels for room 241?)

3. Respond (Here you are.)

A1 You are a business traveler. Request the things on your list.

Example Excuse me. I need to send a fax to Poland.

send a fax to Poland

trousers/ pressing

massage

wake-up call (5.00 a.m. tomorrow)

whisky for the minibar

towels/ changing

today's newspaper

bin/ empting

dress/dry cleaning

more toilet rolls

shirt/ washing

B1 You work in reception. Listen to your partner's requests and make appropriate responses.

You may be able to help directly, or need to contact room service or housekeeping.

Example Certainly, sir/madam. You can send a fax from the business centre.

or I'll send someone up to your room right away.

Planning to assess student understanding is considerable stage in lesson planning. Assessments (e.g., tests, papers, problem sets, performances) provide opportunities for students to demonstrate and practice the knowledge and skills articulated in the learning objectives, and for instructors to offer targeted feedback that can guide further learning.

According to $\mathrm{S}$. Thornbury testing provide us with reliable means of knowing how effective our teaching has been and also provide a form of feedback to both teachers and students as well [11, $\mathrm{p}$. 129]. Testing motivates learners to review vocabulary in preparation for the test, known as backwash. In general, testing helps to "recycle" vocabulary as well as to consolidate it.

Planning for assessment is to find out whether your students are learning. It involves making decisions about:

the number and type of assessment tasks that will best enable students to demonstrate learning objectives for the lesson:

Examples of different assessments,

Formative and/or summative;

the criteria and standards that will be used to make assessment judgements: 
Rubrics;

student roles in the assessment process:

Self-assessment,

Peer assessment;

the weighting of individual assessment tasks and the method by which individual task judgements will be combined into a final grade for the course:

information about how various tasks are to be weighted and combined into an overall grade must be provided to students;

the provision of feedback:

giving feedback to students on how to improve their learning, as well as giving feedback to instructors how to refine their teaching.

Placement tests are intended to provide information which will help to place students at the stage or in the part of the teaching programme most appropriate to their abilities [7, p. 10-14].

ESP is generally used for teaching a utilitarian purpose, to teach to achieve specific language skills using real situations, in a manner that allows students to use English in their future profession. Theoretical learning is good, but not using that knowledge practically is vain. Hence, it is very important to utilize the knowledge practically; otherwise there is no point to gain theoretical knowledge. Practical knowledge can give the best exposure of learning to students and often lead to a deeper understanding of a concept through the act of doing and personal experience. That is why it is necessary to emphasise on the learning process, which means gaining knowledge and the skill of using knowledge [2, p. $330-383]$.

ESP is part of a larger movement within language teaching away from a concentration on teaching grammar and language structures to an emphasis on language in context. ESP covers subjects ranging from hospitality to restaurant management. The ESP focus means that English is not taught as a subject divorced from the students' real world; instead, it is integrated into a subject matter area important to the learners.

Thus, lesson planning provides the following: 1) structure; 2) a logical progression, 3) an emphasis on student involvement, 4) a focus on learning goals and objectives, 5) accountability for skills taught, and 6) an opportunity for teacher reflection. Having a checklist of components that are needed in a lesson plan it is necessary to gain attention and prepare for learning, inform of the learning objective(s), review prior learning and knowledge related to the objective(s), share, model, and describe the content, make the content relevant, check understanding, used a variety of teaching methods, aligned the assessments to the learning objectives, assessed your learning both formatively and summatively, reflected on the outcome to determine successful completion.

\section{ЛІТЕРАТУРА}

1. Методика навчання іноземних мов і культур: теорія і практика: підручник для студ. класичних, педагогічних і лінгвістичних університетів; за заг. ред. С. Ю. Ніколаєвої / Бігич О.Б., Бориско Н. Ф., Борецька Г. Е. та ін. - К.: Ленвіт, 2013. - 590 с.

2. Теорія і практика формування іншомовної професійно орієнтованої компетентності в говорінні у студентів нелінгвістичних спеціальностей: колективна монографія; за заг. і наук. ред. О. Б. Бігич / О. Б. Бігич, Л. В. Бондар, М. М. Волошинова, Л. О. Максименко, О. М. Огуй, І. О. Сімкова, Я. В. Окопна. - К.: Вид. центр КНЛУ, 2013. - 383 с.

3. Anderson L., Krathwohl D. A. Taxonomy for Learning, Teaching and Assessing: A Revision of Bloom's Taxonomy of Educational Objectives. - New York: Longman, 2001. - 352 p.

4. Basturkmen H. Ideas and Options in English for Specific Purposes / Helen Basturkmem. - London: Lawrence Erlbaum Associates, 2006. - 186 p.

1. 5. Dudley-Evans, T. Developments in English for Specific Purposes: a multidisciplinary approach. Cambridge: Cambridge University Press, 2009. - 317 p.

5. Harmer J. The Practice of English Language Teaching / J. Harmer. $-3^{\text {rd }}$ ed. - [S. 1.]: Pearson Education Limited, 2001. $-371 \mathrm{p}$.

6. Hughes, Arthur. Testing for Language Teachers. - Glasgow: Cambridge University Press, 1989. - 172p.

2. 8. Hutchinson Tom, and Waters Alan. English for Specific Purposes: A Learning - centred Approach Cambridge [Cambridgeshire: Cambridge UP, 1987. Print. - 183 p.

8. Longman Dictionary of Language Teaching and Applied Linguistics / Jack C. Richards, Richard Schmidtt. - 4th ed. - Harlaw: Pearson Education Limited, 2010. - 645 p.

9. Tarone E. Focus on the Language Learner / E. Tarone, G. Yule. - Oxford University Press, 1995. - 206 p.

Наукові записки. Серія: педагогіка. - 2018. - № 2. 
10. Thornbury, S. How to Teach Vocabulary. - Harlow: Longman, 2002. - 185 p.

\section{REFERENCES}

1. Medodyka navchannia inozemnych mov i kultur: teoriia i praktyka [Methodology of teaching foreign languages and cultures: theory and practice]: pidruchnyk dlia stud. klasychnykh, pedahohichnych i linhvistychnykh universytetiv / Bihych O. B., Borysko N.F., Boretska H.E. ta in. / za zahaln. red. S. Yu. Nikolaievoii. - K.: Lenvit, 2013. - 590c.

2. Teoriia i praktyka formuvannia inshomovnoi profesiino oriientovanoi kompetentnosti $\mathrm{v}$ govorinni $\mathrm{u}$ studentiv nelinhvistychnyh spetsialnostei [Theory and practice of formation of foreign language professional-oriented competence in speaking among students of non-linguistic specialties]: kolektyvna monohrafiia za zah. i nauk. red O. B. Bihych / O. B. Bihych, L. V.Bondar, M. M. Voloshynova, L. O. Maksymenko, O. M. Ohui, I. O. Simkova, Ya. V. Okopna. - Kyiv: Vyd. tsentr KNLU, 2013. - 383 p.

3. Anderson, L., \& Krathwohl, D. A. Taxonomy for Learning, Teaching and Assessing: A Revision of Bloom's Taxonomy of Educational Objectives. - New York: Longman, 2001. - 352p.

4. Basturkmen H. Ideas and Options in English for Specific Purposes / Helen Basturkmem. - London: Lawrence Erlbaum Associates, 2006. - 186 p.

1. 5. Dudley-Evans, T. Developments in English for Specific Purposes: a multidisciplinary approach. Cambridge: Cambridge University Press, 2009. - 317p.

5. Harmer J. The Practice of English Language Teaching / J. Harmer. $-3^{\text {rd }}$ ed. $-[$ S. 1.]: Pearson Education Limited, 2001. - $371 \mathrm{p}$.

6. Hughes, Arthur. Testing for Language Teachers. - Glasgow: Cambridge University Press, 1989. - 172p.

2. 8. Hutchinson Tom, and Waters Alan. English for Specific Purposes: A Learning - centred Approach Cambridge [Cambridgeshire: Cambridge UP, 1987. Print. - 183p.

8. Longman Dictionary of Language Teaching and Applied Linguistics / Jack C. Richards, Richard Schmidtt. - 4th ed. - Harlaw: Pearson Education Limited, 2010. - 645 p.

9. Tarone E. Focus on the Language Learner / E. Tarone, G. Yule. - Oxford University Press, 1995. - 206 p. 10. Thornbury, S. How to Teach Vocabulary. - Harlow: Longman, 2002. - 185 p.

УдК 378.147:811.111

AGNESSA TOMASHEVSKA

https://orcid.org/0000-0003-3574-5945 agnessat1992@gmail.com

Postgraduate Student

Ternopil Volodymyr Hnatiuk National Pedagogical University

Ternopil, 2 Maksyma Kryvonosa St.

\section{DEVELOPING PROSPECTIVE PHARMACISTS' ENGLISH LEXICAL COMPETENCE IN READING AND SPEAKING THROUGH EXERCISES FOR SELF-DIRECTED STUDY}

The article grounds the main principles of developing prospective pharmacists' English lexical competence in reading and speaking through self-directed study: integrated development of lexical knowledge, skills and lexical awareness in reading and speaking (exercises should be directed to integrated development of all the components of lexical competence), profession-oriented learning (all the texts deal with the topics within the professional area, the main focus is made on professional terms, typical professional situations of intercultural communication), visualization (the vocabulary presented should be visualized to help students create mental pictures), consciousness (e.g., comparing to the corresponding terms in the languages of origin), development of students' strategic awareness, considering lexical unit features. Stages of developing prospective pharmacists' English lexical competence in reading and speaking through self-directed study have been determined: preparatory, which entails semantization of new lexical units and is divided into two sub-stages: the first - getting acquainted with new words out of context (should be applied only for professional terms), the second - getting acquainted with new words in context and building strategic awareness; training - implies automatizing students' actions with new lexical units on the levels of a word, word combination, phrase, sentence, suprasegmental unit; usage - activating students' actions with new lexical units on the text level. A subsystem of exercises for developing prospective pharmacists' English lexical competence in reading and speaking through self-directed study has been worked out. It contains three groups of exercises which correlate with the stages and are subdivided into subgroups. 